\title{
SOSIODEMOGRAFI DAN PEMANTAUAN KLINIK SECARA MANDIRI PENYANDANG DIABETES MELLITUS TIPE II DI RSUD dr.DORIS SYLVANUS PALANGKARAYA
}

\author{
Sosiodemographic And Clinical Monitoring Independently By People With Type II Diabetes Mellitus \\ in RSUD dr. Doris Sylvanus Palangkaraya
}

\author{
1*Nurhalina, ${ }^{2}$ Dwi Purbayanti, ${ }^{3}$ Suratno, ${ }^{3}$ Syahrida Dian Ardhani \\ 1,2,3,4 Universitas Muhammadiyah Palangkaraya, Jl. RTA. Milono Km. 1,5, Palangka Raya, Indonesia \\ *e-mail : nurhalina@umpalangkaraya.ac.id
}

\begin{abstract}
ABSTRAK
Di Kalimantan Tengah upaya-upaya penatalaksanaan DMT2 telah dilakukan guna menekan prevalensi DM dan faktor risiko DM. Berdasarkan hasil Riskesdas 2013, DM merupakan penyakit tertinggi ke 6 (enam) di Kalimantan Tengah dengan prevalensi $1.2 \%$ dan $1.6 \%$ orang dengan gejala diabetes. Berdasarkan rekam medik di RSUD dr.Doris Sylvanus (2015), jumlah pasien DM mengalami peningkatan dari 375 kasus pada Tahun 2014 dan 514 kasus pada Tahun 2015. Tujuan penelitian ini adalah mengetahui sosial demografi dan pemantauan klinik secara mandiri oleh penyandang DMT2 di RSUD Dr.Doris Sylvanus Palangka Raya. Design penelitian adalah ovbservasional dengan pendekatan deskriptif. Populasi dalam penelitian ini adalah penyandang DMT2 yang berkunjung ke RSUD Dr.Doris Sylvanus Palangka Raya pada saat penelitian berlangsung, sedangkan sampel adalah penyandnag DMT2 yang telah didiagnosis lebih dari 1 tahun. Data dikumpulkan melalui wawancara langsung dengan koesioner dan rekam medis responden. Hasil penelitian menunjukan bahwa mayoritas responden berusia lebih dari 50 tahun (76\%), berjenis kelamin penermpuan (59\%), telah menikah (91.8\%), bekerja sebagai PNS/POLRI/TNI (37.2\%) dan tidak bekerja (27.9\%). berdasarkan lama diagnose, mayoritas telah didiagnosa lebih dari 3 tahun (63.4\%).Rata-rata pemantauan klinik secara mandiri responden terhadap kondisi kesehatannya adalah $41.05 \%$ dan terdapat $57.65 \%$ responden yang tidak melakukan pemantaun kesehatan secara rutin. Hasil penelitian juga menunjukan bahwa $100 \%$ responden tidak melakukan pemantauan neuropati dan pemantaun disfungsi ereksi. Sedangkan responden yang melakukan pemantauan $\mathrm{HbA1c}$ hanya berkisar $1.1 \%$.
\end{abstract}

Kata kunci : Pemantauan Klinik, Diabates Militus Tipe II, Sosiodemografi

\begin{abstract}
In Central Kalimantan province efforts to manage type 2 diabetes millitus have been undertaken to reduce the prevalence of case and risk factors. Based on the results of Riskesdas 2013.Medical records of Doris Sylvanus Hospital in 2015, the number of diabetes millitus patients has increased from 375 cases in 2014 and 514 cases in 2015. The purpose of this study was to determine the sociodemographic and clinical monitoring independently by people with type 2 diabetes mellitus. Design studyis ovbservasional with descriptive approach were population is people with type 2 diabetes millitus who visited Dr.Doris Sylvanus Palangka Raya hospitaland had been diagnosed for more than 1 year. Data were collected through direct interviews with respondents and medical records of respondents. The results showed thatthe majority of respondents were more than 50 years old (76\%), female (59\%), were married (91.8\%), worked as civil servants / police / military (37.2\%) and did not work (27.9\%). based on the length of diagnosis, the majority have been diagnosed for more than 3 years (63.4\%).The average independent clinical monitoring of respondents for their health condition was $41.05 \%$ and there were $57.65 \%$ of respondents who did not conduct routine health monitoring. The results also showed that 100\% of respondents did not monitor neuropathy and monitor erectile dysfunction. Whereas respondents who monitor HbAlc are only around $1.1 \%$.
\end{abstract}

Keyword: Sosiodemographic, Type 2 Diabetes Millitus, Clinical Monitoring

\section{PENDAHULUAN}

Indonesia merupakan negara ke -7 (tujuh) dengan prevalensi Diabetes Millitus tertinggi di dunia setelah Cina, India, USA, Brazil, Rusia dan
Meksiko. Sedangkan prevalensi DM di Indonesia mencapai 8.4 juta orang dan diprediksi akan meningkat 21.3 juta jiwa pada tahun 2030. Diabetes Federation (IDF) mengemukakan bahwa Diabetes Militus Tipe 2 (DMT2) merupakan tipe Diabetes 
Militus (DM) yang paling umum ditemukan (90\%) dibandingkan DM tipe 1, DM Gestasional dan DM tipe lain (Kementrian Kesehatan RI, 2017).

\section{Global Status Report on NCD World Health} Organization (2014) melaporkan bahwa kematian akibat Diabetes Millitus (DM) menduduki peringkat ke 6 (enam), dengan rata-rata angka kematian 1.3 juta orang per tahun. Di Asia Tenggara terdapat 46 juta jiwa menderita DM dan diperkirakan meningkat hingga 119 juta jiwa pada Tahun 2030. Sedangkan penderita DM di Indonesia mencapai 8.4 juta orang dan diprediksi akan meningkat hingga 21.3 juta jiwa pada Tahun 2030. Angka tersebut menjadikan Indonesia sebagai negara dengan urutan ke-7 (tujuh) prevalensi DM tertinggi setelah Cina, India, USA, Brazil, Rusia dan Meksiko.

DMT2 merupakan penyakit multifaktorial dengan komponen genetik dan lingkungan yang saling mempengaruhi. Penelitian Ricardo, Damayanti, Nelly (2014), menyebutkan bahwa kejadian DMT2 berhubungan signifikan dengan usia, obesitas, resistensi insulin, makanan, aktifitas fisik, riwayat DM dan gaya hidup seseorang. Menurut Waspadji, S., Soewondo, P., Subekti, I., Soebardi, S., Harbuwono, D. S., Pramono, L. A. and Supali, T. (2013), DMT2 akan mengakibatkan berbagai komplikasi jika tidak dikelolah dengan baik seperti Penyakit Jantung Koroner, gangguan pada pembuluh darah tepi serta gangguan pada pembuluh darah otak yang dapat menimbulkan stroke. Berdasarkan penelitian epidemiologi penyandang DMT2 memiliki risiko 2 kali lebih besar mengalami PJK dan penyakit pembuluh darah otak, 5 kali lebih besar mengalami gangrene serta 0.77 kali lebih mudah mengalami gagal ginjal terminal dan 25 kali lebih mudah mengalami kebutaaan akibat kerusakan retina daripada orang dengan tidak diabetes.

Dalam konsensus pengelolaan dan pencegahan DMT2 di Indonesia Tahun 2015, penatalaksanaan dan pengelolaan DM dititikberatkan pada 4 pilar yaitu edukasi, terapi nutrisi medis (TNM), latihan jasmani dan intervensi farmakologis (PERKENI, 2015). Selain itu seorang penderita DM harus melakukan kontrol glukosa darah secara rutin, salah satunya adalah pemeriksaan HbAlc.Nilai HbA1c dapat digunakan untuk mengetahui status kendali glikemik/ metabolic dalam memantau hasil
pengobatan.Menurut

Cllinical

Pratice

Recommendations American Diabetes Association (ADA) nilai sasaran HbA1c pada pasien DM adalah $>7.0 \%$ sebagai tanda status metabolik yang baik, pedoman umum untuk mencegah/ mengurangi risiko penyulit mikroskular (misalnya retina dan ginjal) dan saraf (neuropati dan disfungsi eretik).

Di Kalimantan Tengah upaya-upaya penatalaksanaan DMT2 telah dilakukan guna menekan prevalensi DM dan faktor risiko DM. Berdasarkan hasil Riskesdas 2013, DM merupakan penyakit tertinggi ke 6 (enam) di Kalimantan Tengah dengan prevalensi $1.2 \%$ dan $1.6 \%$ orang dengan gejala diabetes. Berdasarkan rekam medik di RSUD dr.Doris Sylvanus (2015), jumlah pasien DM mengalami peningkatan dari 375 kasus pada Tahun 2014 dan 514 kasus pada Tahun 2015. Berdasarkan informasi upaya-upaya penatalaksanaan DM pada umumnya merupakan tanggung jawab pasien dan dokter di lini depan. Namun banyak kalangan menilai bahwa hal tersebut tidak efektif dalam menekan laju morbiditas dan mortalitas akibat DM di Kalimantan Tengah.Hasil penelitian diharapkan dapat bermanfaat untuk pengembangan ilmu pengetahuan dan teknologi dalam Bidang Kedokteran dan memberikan informasi kepada instansi terkait guna pengendalian DMT2 di Kalimantan Tengah dan di Indonesia pada umumnya.

\section{METODE PENELITIAN}

\section{Jenis Penelitian}

Desain penelitian ini adalah observasional Study untuk mengetahui karakteristik penderita DMT2 yang menjalani terapi di RSUD Dr.Doris Sylvanus palangka Raya.

\section{Populasi dan Sampel}

Populasi dalam penelitian ini adalah penderita DMT2 yang berkunjung ke RSUD dr.Doris Sylvanus pada saat penelitian berlangsung. Semua populasi diminta untuk mengisi informed consent dan persetujuan untuk berpartisipasi dalam penelitian. Teknik penarikan sampel dilakukan secara purposive sampling dengan kriteria penderita DMT2 yang telah didiagnosas $>1$ (satu) tahun. Sampel dalam penelitian ini berjumlah 183 orang. 


\section{Analisis Data}

Pengumpulan data dilakukan melalui wawancara menggunakan koesioner untuk mengetahui usia, jenis kelamin, perilaku merokok, riwayat pernikaha, perilaku meminum alkohol, lama menderita diabetes, riwayat keluarga dengan diabetes, TMT responden dan jenis pekerjaan. Sedangkan pemantauan klinik responden diperoleh melalui catatan rekam medis responden yang diperoleh dari RSUD Dr.Doris Sylvanus. Data yang dikumpulkan meliputi pemantauan HbA1c, pemantauan enzim hati, retinopati, neuropati, nefropati, disfungsi ereksi, abses luka, tekanan darah dan profil lipid. Semua data diolah dan dianalisis secara univariat melalui tahapan pemeriksaan data, pengokodean data, pengkategorian data, tabulasi data, penarikan kesimpulan dan intreprestasi hasil

\section{HASIL DAN PEMBAHASAN}

Studi di lakukan di Rumah Sakit Umum Daerah dr. Doris Sylvanus Palangka Raya pada bulan September sampai desember 2017. Tabel 4.1.2 menunjukan bahwa mayoritas responden $(69.9 \%)$ telah mengalami komplikasi dan $46.9 \%$ diantaranya menderita lebih dari 1 komplikasi. Berdasarkan informasi mayoritas komplikasi awal responden adalah Hipertensi (39.8 \%) diikuti gangguan penglihatan $(30.5 \%)$.

TABEL 1. Karakteristik Responden di RSUD Dr. Doris Sylvanus Palangka Raya Tahun 2017

\begin{tabular}{lcc}
\hline \multirow{2}{*}{ Karakteristik } & \multicolumn{2}{c}{ Frekuensi } \\
\cline { 2 - 3 } & Jumlah (n) & Persentase (\%) \\
\hline Usia & & \\
$\leq 19$ tahun & 0 & 0.0 \\
19-24 tahun & 1 & 0.5 \\
$25-29$ tahun & 0 & 0.0 \\
$30-34$ tahun & 4 & 2.2 \\
35-39 tahun & 9 & 4.9 \\
40-44 tahun & 0 & 0.0 \\
45-49 ahun & 30 & 16.4 \\
$\geq$ 50 tahun & 139 & 76.0 \\
Jenis Kelamin & & \\
Laki-laki & 75 & 41.0 \\
Perempuan & 108 & 59.0 \\
Status Pernikahan & & \\
Belum Menikah & 5 & 2.7 \\
Menikah & 168 & 91.8 \\
Cerai Hidup & 4 & 2.2 \\
Cerai Mati & 6 & 3.3 \\
Jenis Pekerjaan & & \\
PNS/ TNI/ POLRI & & \\
Wiraswasta & 68 & 37.2 \\
Karyawan Swasta & 51 & 27.9 \\
dan Lain-lain & 6 & \\
\hline
\end{tabular}

\begin{tabular}{lcc} 
Tidak Bekerja & 7 & 3.8 \\
& 51 & 27.9 \\
Lama Terdiagnosa DM & & \\
Lebih dari 3 tahun & 116 & 63.4 \\
1-3 tahun & 33 & 18.0 \\
Kurang dari 1 tahun & 34 & 18.6 \\
\hline
\end{tabular}

Tabel 1 menunjukan bahwa mayoritas responden berusia $\geq 60$ tahun sebesar $76.0 \%$ dan tidak ada responden yang berusia $\leq 19$ tahun dan 25-29 tahun $(0.0 \%)$. Berdasarkan jenis kelamin, mayoritas responden berjenis kelamin perempuan $(59.0 \%)$. Sedangkan berdasarkan status pernikahan mayoritas responden menikah (98.0\%) dan terdapat $2.7 \%$ responden yang belum menikah. Dalam penelitian ini diperoleh juga informasi bahwa $41.0 \%$ responden mempunyai riwayat keluarga dengan DM yang berasal dari ayah maupun ibu. Mayoritas responden bekerja sebagai PNS/ POLRI/ TNI (37.2 \%) dan wiraswasta $(27.9 \%)$ dimana tidak jauh berbeda presentasenya dengan responden yang tidak bekerja yaitu $27.9 \%$. Berdasarkan riwayat merokok, terdapat $20.8 \%$ responden yang pernah merokok, sedangkan berdasarkan riwayat alkohol terdapat 1.1 $\%$ responden yang pernah mengkonsumsi alkohol. Mayoritas responden telah didiagnosa DM lebih dari 3 tahun $(63.4 \%)$.

Berdasarkan TMT responden, terdapat $36.1 \%$ responden yang mengalami obesitas dan $2.7 \%$ responden yang mengalami penurunan berat badan (kurus). Sedangkan berdasarkan pmantauan mandiri kondisi kesehatan responden dilihat berdasarkan beberapa indikator yaitu pemantauan gula darah, pemantauan profil lipid, pemantauan tekanan darah, pemantauan nefropati diabetik, pemantauan neuropati, pemantauan retinopati, pemantauan ulkus dan pemantauan perlemakan hati. Adapun gambaran pemantauan mandiri responden dapat dilihat pada Tabel 2 berikut.

TABEL 2. Pemantauan Klinik Secara Mandiri

\begin{tabular}{lccccc}
\hline $\begin{array}{l}\text { Pemantauan } \\
\text { Klinik Secara }\end{array}$ & \multicolumn{2}{c}{ Tidak } & \multicolumn{2}{c}{ Ya } & \multirow{2}{*}{ Total } \\
\cline { 2 - 5 } \multicolumn{1}{c}{ Mandiri } & n & \% & n & \% & \\
\hline $\begin{array}{l}\text { Tekanan } \\
\text { Darah }\end{array}$ & 105 & 57.4 & 78 & 42.6 & 183 \\
Gula Darah & 120 & 65.6 & 63 & 34.4 & 183 \\
Profil Lipid & 149 & 81.4 & 34 & 18.4 & 183 \\
Neuropati & 183 & 100.0 & 0 & 0.0 & 183 \\
Nefropati & 136 & 74.3 & 47 & 25.7 & 183 \\
Retinopati & 181 & 98.9 & 2 & 1.1 & 183
\end{tabular}




$\begin{array}{llllll}\text { Perlemakan } & 181 & 98.9 & 2 & 1.1 & 183 \\ \begin{array}{l}\text { Hati } \\ \text { Pemantauan }\end{array} & 0 & 0.0 & 183 & 100.0 & 183 \\ \begin{array}{l}\text { Ulkus } \\ \text { Disfungsi }\end{array} & 183 & 100.0 & 0 & 0.00 & 183 \\ \begin{array}{l}\text { Ereksi } \\ \text { HbA1c }\end{array} & 181 & 98.9 & 2 & 1.1 & 183 \\ \text { Rerata } & \mathbf{1 0 5 . 5} & \mathbf{5 7 . 6 5} & \mathbf{7 7 . 5} & \mathbf{4 1 . 0 5} & \mathbf{1 8 3}\end{array}$

Tabel 2 menunjukan bahwa rata-rata pemantauan mandiri responden terhadap kondisi kesehatannya adalah $41.05 \%$ dan terdapat $57.65 \%$ responden yang tidak melakukan pemantaun kesehatan secara rutin. Hasil penelitian juga menunjukan bahwa $100 \%$ responden tidak melakukan pemantauan neuropati dan pemantaun disfungsi ereksi. Sedangkan responden yang melakukan pemantauan $\mathrm{HbA} 1 \mathrm{c}$ hanya berkisar $1.1 \%$.

Populasi study adalah orang dewasa yang telah didiagnosa diabetes lebih dari 1 (satu) tahun. Hasil penelitian menunjukan prevalensi DMT2 mayoritas berusia lebih dari 50 tahun (76\%). Jumlah ini telah dilaporkan mengalami peningkatan secara signifikan diantara individu yang berusia 50 tahun ke atas, setidaknya $20 \%$ masyarakat yang berusia 65 tahun keatas mengalami diabetes (Kementrian Kesehatan RI, 2017).Penelitian Bella Yunita dan Evi Kurniawaty (2016) menunjukan bahwa prevalensi diabetes meningkat secara signifikan pada usia diatas 50 tahun karena penuaan menyebabkan menurunnya sensitivitas insulin dan menurunnya fungsi organ tubuh untuk metabolism glukosa. Sejalan dengan penelitian Suastika (2005) bahwa prevalensi DM pada usia lanjut meningkat tiga kali lipat jika dibandingkan dengan kelompok yang kebih mudadan terjadi pada orang dewasa di bawah 50 tahun karena kontrol metabolik yang buruk, bahkan diantaranya disertai dengan komorbiditas yang mempengaruhi kualitas hidup mereka.

Berdasarkan jenis kelamin, sebagian besar responden dalam penelitian ini adalah perempuan (51 \%). Laporan Kementrian Kesehatan RI (2017) menunjukkan bahwa tidak adanya perbedaan gender yang signifikan dalam proporsi diabetes di Indonesia. Penelitian DL Alloreng, Sekplin A.S.Sekeon, Wooford B.S. Joseph (2016) bahwa perempuan berisiko 2,777 kali lebih besar dibandingkan dengan laki-laki. Hal ini berhubungan dengan hormone kehamilan yang dapat menurunkan fungsi insulin dan secara fisik wanita memiliki peluang mengalami peningkatan indeks masa tubuh yang lebih besar disbanding laki-laki.

Begitupula dengan status perkawinan, sebagian besar responden sudah menikah (91.8\%) dan belum menikah (1.7\%).Variabel hubungan sosial iniakan mempengaruhi kontrol glukosa darah, karena pada umumnya penderitamenyadari bahwa penyakit mereka dapat mengganggudinamika dalamberkeluarga (Torquato MTCG, Montenegro RM, Viana LAL, Souza RAHG, Lanna JCB, Durin,CB et al, 2001). Keluarga yang tidak harmoniskerapkalimempengaruhi kepatuhan pasien dalam pengobatankontrol glikemia, lipid dan lainnya.Sebaliknya keluarga yang harmonis dapat memberikan dukungan terhadap perawatan kesehatan penderita dan mempengaruhi perilakumereka terhadap penyakit ini sertamendukung penderita untuk senantiasa mengontrol dan memantau kondisi kesehatannya (Rodriguez MM, Guerrero JFR, 1997).

Berdasarkan hasil penelitian sebesar $5.5 \%$ diantara mereka telah menjadi janda/ duda. Faktor ini bisa mempengaruhi menajemen diabetes, karena dalam beberapa kasus kehilangan pasangan seseorang menyebabkan perubahan kesehatan seperti depresi, cemas dan kehilangan keinginan untuk hidup (Liudmida Miyar Otero, Maria Lucia Zaneti, Tara Regina de Souza Teixeira,2007). Berdasarkan pekerjaan sebagian besar berasal dari unsur aparat Sipil Negara (ASN)/ TNI/POLRI ( 37\%), wiraswasta dan tidak bekerja (27\%). Kelompok tidak bekerja, sebagian besar adalah pensiunan, hal ini sesuai dengan proporsi penyandang DM dalam penelitian ini, dimana sebagian besar berusia lebih dari 50 tahun.Banyak penderita diabetes mengalami masalah karena biaya pengobatan, sehingga mempengaruhi kemampuan mereka untuk mendapatkan perawatan penting untuk kontrol diabetes dan manajemen diri (Brown et al., 2009)

Berdasarkan waktu diagnosis, pada mayoritas responden sangat terlambat untuk didiagnosa. Selain itu terdapat subdiagnosis untuk penderita, karena biasanya penderita datang ke fasilitas kesehatansetelah mengalami beberapa jenis komplikasi ketika didiagnosis. Hasil penelitian menunjukan bahwa retinopati akan terjadi setelah 7 tahun menderita diabetes begitupula risiko penyakit jantung dan penyakit pembuluh darah perifer. 
Kondisi ini akan semakin parah jika DMT2 terlambat didiagnosis (Spijkerman AMW, Dekker JM, Nijpels G, Marcel C, Adriaanse MC, Dirk KJP et al, 2003).

Berdasarkan konsesus Perkeni Tahun 2015, penatalaksanaan penyandang DM meliputi : (a) Gizi seimbang dengan diit teratur; (b) Meningkatkan pengetahuan tentang penyakit yang diderita dalam hal ini Penyakit DM; (c) Latihan fisik (olah raga) yang teratur; (d) Terapi medis. Selain itu penderita juga dianjurkan untuk melakukan pemantauan mandiri terhadap kondisi kesehatan meliputi pemantauan kadar gula, pemantauan tekanan darah, pemantauan HbA1c, pemantauan nefropati diabetik, pemantauan neuropati, pemantauan ulkus, pemantauan retinopati dan pemantauan perlemakan hati.

Menurut Atak, Tanju dan Kenan (2010) manajemen diri merupakan kunci penatalaksanaan penyakit kronis secara komprehensif termasuk pengendalian komplikasi pada penderita Diabetes Militus. Manajemen diri penderita DM yang efektif diperoleh jika individu memiliki pengetahuan dan keterampilan untuk melakukan pengelolaan penyakitnya secara mandiri. Keberhasilan manajemen diri membutuhkan partisipasi penderita, keluarga dan masyarakat secara berkelanjutan atau yang disebut Diabetes Self Management Education (DSME) yang meliputi pemahaman tentang penyakit DM, makna dan perlunya pengendalian serta pemantauan mandiri DM , intervensi farmakologi dan non farmakologi, hipoglikemi, hiperglikemi serta penyulit lain yang dihadapi, cara menggunakan jenis perawatan yang tersedia (Funnel, Brown, Childs, Haas, Hosey, dkk, 2010).

Hasil penelitian menunjukan bahwa tingkat kemandirian responden dalam memantau kesehatannya cukup rendah yaitu rata-rata $41.05 \%$, sedangkan responden yang memantau kesehatannya rata-rata $57.65 \%$. Berdasarkan hasil observasi diperoleh informasi bahwa semua responden (100\%) tidak pernah melakukan pemantauan neuropati dan pemantauan disfungsi ereksi. Selain itu penelitian ini juga menemukan bahwa98.9\% responden tidak pernah melakukan pemantauan HbA1c, pemantauan retinopati, pemantauan enzim hati dan pemantauan retinopati setelah didiagnosa diabetes. Sebagian besar responden hanya melakukan pemantauan tekanan darah $(42.6 \%)$, pemantauan gula darah $(34.4 \%)$ dan pemantauan profil lipid (18.4\%).

Banyak variabel dapat mempengaruhi manajemen diri diabetes. Menurut model kepercayaan kesehatan (Rosenstock, 1974)bahwa persepsi individu tentang kerentanan dan keseriusan suatu penyakit serta persepsi tentang manfaat dan hambatan untuk melakukan diagnosa dini, pemantauan klinik dan pengobatansangat dipengaruhi oleh faktor sosiodemografi penderita, faktor psikososial dan sosial budaya dalam masyarakat. Selain itu faktor eksternal juga mempengaruhi kepatuhan penderita dalam manajemen diri diabetes, yang mencakup dukungan dari keluarga, teman sebaya, dan perilaku penyedia layanan kesehatan yang mendorong penderita untuk bertindak, memberikan bantuan langsung kepada penderita, memberikan motivasi dan memberikan edukasi tentang diabetes.

Namun terdapat faktor internal yang mungkin dapat menghambat manajemen diri penderitadiabetes yang meliputi ketakutan yang terkait dengan pemantauan glukosa, kurangnya kontrol diri lebih dari kebiasaan diet, melemahnya daya ingat,dan kurangnya kontrol personal terhadap diabetes (Chlebowy, Hood, \&LaJoie, 2010). Pasien dengan diabetes dan melek huruf yang rendah memiliki pengetahuan buruk tentang penyakit mereka dan mungkin memiliki kesulitan mempelajari keterampilan perawatan diri lanjutan yang diperlukan (Bryant et al., 2004).Namun keterbatasan penelitian ini, kami tidak menggali lebih jauh tentang sejauh mana ketakutan pasien untuk melakukan pemantauan klinik secara mandiri dan tidak menguji sejauh mana daya ingat responden dan hal-hal kecil yang dilakukan untuk menghadapi penyakit yang diderita.

Selain itu manajemen diri diabetes juga dipengaruhi oleh usia klien, pengaruh budaya, kepercayaan dan sikap tenaga kesehatan, pengetahuan diabetes, keterampilan dan perilaku manajemen diri, kesiapan untuk belajar, keterbatasan fisik, dukungan keluarga, dan status sosial ekonomi (Brown et al., 2009). Namun kelemahan penelitian ini, kami tidak mendapatkan informasi sejauh mana dukungan keluarga terhadap perawatan dan managemen diri presponden yang berkaitan dengan diabetes. 
Tekanan waktu mungkin merupakan faktor lain yang mempengaruhi manajemen diri diabetes. Menurut Russell, Safford dan Suh (2005), pasien lanjut usia dan pasien dengan komplikasi diabetes jangka panjang (gangguan neurologis / stroke,neuropati, gangguan penglihatan, atau depresi) dapat membutuhkan dua kali lebih lama untuk sebagian besar manajemen diri diabetes tugas dan mungkin juga membutuhkan bantuan pengasuh. Mereka mungkin tidak dapat melakukan beberapa tugas, seperti berolahraga, karena kurangnya waktu yang cukup, terutama dengan adanya keterbatasan fisik.

\section{KESIMPULAN}

Dalam penelitian ini menunjukan bahwa mayoritas responden berusia lebih dari 50 tahun (76\%), berjenis kelamin penermpuan (59\%), telah menikah $(91.8 \%)$, bekerja sebagai PNS/POLRI/TNI (37.2\%) dan tidak bekerja (27.9\%). berdasarkan lama diagnose, mayoritas telah didiagnosa lebih dari 3 tahun (63.4\%).Rata-rata pemantauan klinik secara mandiri responden terhadap kondisi kesehatannya adalah $41.05 \%$ dan terdapat $57.65 \%$ responden yang tidak melakukan pemantaun kesehatan secara rutin. Hasil penelitian juga menunjukan bahwa $100 \%$ responden tidak melakukan pemantauan neuropati dan pemantaun disfungsi ereksi. Sedangkan responden yang melakukan pemantauan $\mathrm{HbA1c}$ hanya berkisar $1.1 \%$.

\section{DAFTAR PUSTAKA}

Atak, N.,Tanju,G,.Kenan, K. 2010. The Effect of Education on Knowledge, Self Management and Self Efficacy With Type II Diabetes. Australian Journal of Advanced Nursing. 26 (2). pp: 66-74

B Yanita \& E Kurniawati. 2016. Faktor-faktor yang berhubungan dengan kejadian Diabetes Militus Tipe II. Jurnal Majority. 25 (2).

Bryant, P., Trinder, J. \& Curtis, N. 2004. Sick and tired: does sleep have a vital role in the immune system?. Nat Rev Immunol: 4. pp: $457-467$
Chireh, B., Li, M., \& D'Arcy, C. 2019. Diabetes increases the risk of depression: A systematic review, meta-analysis and estimates of population attributable fractions based on prospective studies. Preventive medicine reports, 14

DL Alloreng, Sekplin A.S.Sekeon, Wooford B.S. Joseph. 2016 .Hubungan antara umur, jenis kelamin, dan tingkat pendidikan dengan kejadian Diabetes Militus Tipe II di Puskesmas Ranotana Weru Kota Manado Tahun 2016.FKM UNSRAT

Funnel,M.,Brown,T.,Childs,B.,Hass,L.,.Hosey,G.,Jes en,B,. 2010.National Standard for Diabetes Self-management Education. Diabetes Care.30 (6). pp:1630-163

Liudmida Miyar Otero, Maria Lucia Zaneti, Tara Regina de Souza Teixeira. 2007 Sociodemographic and clinical characteristics of a diabetic population at a primary level health care center. Rev Latino-am Enfermagem pp: 768-73

Kementrian Kesehatan RI.2017. Laporan Riset Kesehatan Dasar Tahun 2017. Kemenkes RI; Jakarta

Orr Chlebowy, D., Hood, S., \& LaJoie, A. S. 2010. Facilitators and Barriers to Self-management of Type 2 Diabetes Among Urban African American Adults. The Diabetes Educator, 36(6), pp: 897-905.

Perkeni.2015. Konsensus Perkeni.Konsensus Pengelolaan dan Pencegahan Diabetes Militus Type 2 di Indonesia Tahun 2015. PB Perkeni : Jakarta

Rodriguez MM, Guerrero JFR. 1997. Importancia del apoyo familiar en el control de la glicemia. Salud Pública Méx. 39 (1), pp: 44-7.

Rosenstock, I. M. 1974. The Health Belief Model and Preventive Health Behavior. Health Education Monographs, 2(4), pp: 354-386.

Suastika K, Achmad B, Gotera W, Budhiarta AAG, Sutanegara D. 2005. Smoking was not associated with insulin resistance in population of Bali. Ann Internal Medecine.Sanglah Hospital. Bali: Udayanan University Press 


\section{BJMLT}

Spijkerman AMW, Dekker JM, Nijpels G, Marcel C, Adriaanse MC, Dirk KJP. 2003. Microvascular complications at time of diagnosis of type 2 diabetes are similar among diabetic patients detected by targeted screening and patients newly diagnosed in general practice: the Hoorn screening study. Diabetes Care. 26 (9), pp: 2648

Safford MM, Russell, Suh DC, Roman S, Pogach L. 2005. How much time do patients with diabetes spend on self-care ?. J Am Board Fam Pract.18 (4) pp; 262

Torquato MTCG, Montenegro RM, Viana LAL, Souza RAHG, Lanna JCB, Durin,CB. 2001. Prevalência do diabetes mellitus, diminuição da tolerância à glicose e fatores de risco cardiovascular em uma população urbana adulta de Ribeirão Preto. Diabetes Clín. 5(3) pp:183-9

WHO. 2015. Global Status Report Non Communicable Desease 2014. World Health Organization

Waspadji, S., Soewondo, P., Subekti, I., Soebardi, S., Harbuwono, D. S., Pramono, L. A. and Supali, T. 2013. "Ende Diabetes Study: diabetes and its characteristics in rural area of East Nusa Tenggara", Medical Journal of Indonesia, 22 (1), pp: 30-8. 